\title{
PERBEDAAN HASIL DETEKSI PEWARNAAN BAKTERI TAHAN ASAM DAN RAPID ANTIGEN PADA PASIEN DIAGNOSA TUBERKULOSIS PARU
}

\author{
Farida Ariyani ${ }^{1}$, Maulin Inggriani ${ }^{2}$, Noor Andryan Ilsan ${ }^{3 *}$ \\ 1. Laboratorium Diagnostik, Rumah Sakit Mitra Keluarga Depok, Depok-Indonesia \\ 2. Program Studi DIII TLM, STIKes Mitra Keluarga, Bekasi-Indonesia \\ 3. Program Studi DIII TLM, STIKes Mitra Keluarga, Bekasi-Indonesia
}

*Korespondensi: Noor Andryan Ilsan | STIKes Mitra Keluarga | noorandryanilsan@ gmail.com

\begin{abstract}
Abstrak
Pendahuluan: Tuberkulosis atau TB paru merupakan penyakit infeksi kronis yang sering dikaitkan dengan daerah urban, populasi yang padat dan ventilasi bangunan yang buruk. Tuberkulosis adalah penyakit yang disebabkan oleh Mycobacteriun tuberculosis. World Health Organization (WHO) melaporkan 9 juta kasus dan 1,4 juta kematian disebabkan oleh TB. Berdasarkan data pengendalian TB tahun 2010, Indonesia menduduki peringkat kelima sebagai penyumbang kasus terbanyak di dunia. Diagnosa utama TB ditegakkan bedasarkan keberadaan Bakteri Tahan Asam (BTA) pada pemeriksaan mikroskopis. Pemeriksaan mikroskopis memiliki kelemahan yaitu memiliki spesifisitas dan sensitivitas yang relatif rendah. Pemeriksaan terkini M.Tb Ag rapid test merupakan uji serologi yang mendeteksi antigen protein yang disekresi Mycobacterium tuberculosis. Penelitian ini bertujuan untuk mengetahui perbedaan hasil pewarnaan BTA metode Ziehl Neelsen secara mikroskopis dengan M.Tb Ag rapid test pada pasien yang didiagnosa klinis TB paru.
\end{abstract}

Metode: Penelitian ini menggunakan observasi cross sectional. Sampel penelitian berupa sputum dari pasien dengan klinis TB paru sebanyak 40 sampel dengan populasi pasien dengan klinis TB. Analisis data menggunakan uji hipotesis chi-square.

Hasil: Data yang diperoleh dianalisis menggunakan chi-square dari hasil perhitungan didapatkan hasil yang signifikan yaitu sig 0,001 (sig <0,05). Pada penelitian ini diketahui bahwa kasus positif TB pada pasien perempuan lebih tinggi (55\%) dibandingkan dengan laki-laki (45\%)

Kesimpulan: Terdapat perbedaan yang signifikan antara hasil pewarnaan BTA mikroskopis dengan pemeriksaan M.Tb Ag rapid test pada pasien diagnosa klinis TB paru.

Kata Kunci: TB paru, M.Tb Ag rapid, Pewarnaan BTA, Kejadian TB paru, Ziehl Neelsen.

\section{Diterima 1 Mei 2019; Accepted 30 Juni 2019}

\section{PENDAHULUAN}

Tuberkulosis atau TB paru merupakan penyakit infeksi kronis yang sering dikaitkan dengan daerah urban, populasi yang padat dan ventilasi bangunan yang buruk. TB adalah penyakit yang disebabkan oleh Mycobacteriun tuberculosis. Bakteri ini mempunyai sifat tahan terhadap pewarna asam sehingga dinamai bakteri tahan asam (BTA). Peran tenaga Teknologi Laboratorium Medik diharapkan mampu memeriksa sediaan yang sesuai dengan standar WHO. Pemeriksaan pewarnaan BTA secara mikroskopis pada sputum dalam diagnosis TB termasuk pemeriksaan sederhana, mudah dikerjakan, tidak mahal dan tidak memerlukan teknologi yang canggih. Pemeriksaan yang lain untuk diagnosis TB seperti kultur dan PCR tidak umum dilakukan di laboratorium karena memerlukan fasilitas dan kelengkapan alat yang canggih. Prioritas utama dari program pengobatan TB dilakukan pada pasien dengan BTA positif. Tujuan pemeriksaan sputum TB secara mikroskopis untuk mendiagnosis TB dan monitoring pemberian terapi. Penegakkan diagnosis TB diperlukan pemeriksaan sputum tiga kali yaitu sewaktu, pagi, sewaktu dan untuk membantu terapi TB diperlukan dua kali pemeriksaan yaitu pagi dan sewaktu (PBPK, 2009).

TB merupakan salah satu masalah global yang utama. WHO melaporkan 9 juta kasus dan 1,4 juta kematian disebabkan oleh tuberkulosis (WHO, 2012). Berdasarkan data pengendalian TB tahun 2010, prevalensi TB di Indonesia adalah 285 per 100.000 penduduk. Indonesia menduduki peringkat kelima sebagai penyumbang kasus terbanyak di dunia. Hal ini membaik dari tahun-tahun sebelumnya dimana Indonesia menduduki peringkat ketiga dunia (Kemenkes, 2012).

Deteksi dengan pewarnaan BTA dipilih karena hal ekonomis, namun keterbatasan metode ini sangat dipengaruhi oleh beberapa faktor luar seperti kualitas pewarnaan dan keahlian pemeriksa mengakibatkan 
ketidak akuratan pemeriksaan. Standar terbaik dalam pemeriksaan TB adalah kultur bakteri, namun tahapan ini memiliki kelemahan karena dinilai terlalu lama dalam memberikan hasil (Nazarudin et al., 2012). Akibat dari beberapa kelemahan pemeriksaan BTA secara mikroskopis dan kultur, beberapa produsen mengembangkan alat pemeriksaan deteksi $M$. tuberculosis yang dinilai dapat mempermudah prosedur pemeriksaan, memberikan hasil yang cepat namun tetap berkualitas.

Saat ini tes cepat yang berkembang di Indonesia diantaranya adalah Mycobacterium tuberculosis Antigen rapid (M.Tb Ag Rapid Tes). Pemeriksaan ini merupakan uji serologi untuk mendeteksi antigen M. tuberculosis. Tb antibodi monoclonal terhadap antigen yang dikode gen RD1, RD2 dan RD3 digunakan untuk mendeteksi antigen ESAT-6, CFP-10 dan MPb64. Tiga genomic RD (Regions Of Different) yaitu RD1, RD2 dan RD3 dan dapat dilakukan cepat praktis dan mudah (Nazarudin et al., 2012). Gen yang menjadi ESAT6, CFP10 dan MPb64 terdapat pada region RD yang terdeteksi ini sehingga RD1- RD3 diduga kuat sebagai gen virulensi yang dimiliki oleh M. tuberculosis (Gustiani et al., 2014). Tujuan Penelitian ini adalah untuk mengetahui perbedaan hasil pewarnaan BTA metode Ziehl Neelsen dan M.Tb rapid antigen pada sputum pasien TB paru juga distribusi sampel berdasarkan jenis kelamin dan kelompok umur.

\section{METODE}

Penelitian menggunakan desain observasi analitik dengan pendekatan cross sectional. Sampel yang digunakan sebanyak 40 sampel merupakan data rawat inap maupun rawat jalan yang melakukan pemeriksaan pewarnaan BTA dan MTb Ag rapid test. Data dianalisis menggunakan uji statistik ChiSquare.

\section{Pemeriksaan TB menggunakan Pewarnaan Ziehl Neelsen spesimen sputum}

Sampel yang digunakan adalah sputum sewaktu, yaitu sputum pertama yang dikumpulkan pada saat pasien datang berkunjung pertama kali dan pada saat pulang. Sputum yang sudah diperoleh dimasukkan ke dalam pot yang berulir pada bagian leher pot. Penyimpanan spesimen sputum kurang dari satu jam. Pewarnaan BTA menggunakan pewarnaan Ziehl Neelsen (ZN). Bakteri Tahan Asam terlihat berwarna merah dengan latar belakang berwarna biru setelah dilakukan pewarnaan ZN.

Langkah awal dalam pewarnaan ZN adalah pembuatan preparat. Satu ose sputum diambil kemudian diratakan pada permukaan kaca objek dengan cara sinculer (memutar dari dalam keluar) lalu dibiarkan kering di udara. Preparat tersebut difiksasi diatas api bunsen. Larutan carbol fuchsin 1\% dituang pada seluruh permukaan sediaan, kemudian dipanaskan diatas nyala api sampai keluar asap tetapi tidak sampai mendidih atau kering selama 5 menit. Sediaan kemudian dibiarkan dingin selama 5-7 menit. Larutan asam alkohol 3\% (hydrochloric acid-ethanol) dituang pada sediaan dan biarkan 2-4 menit, kemudian dicuci dengan air mengalir selama 1-3 menit. Larutan methylene blue 0,1\% dituang sampai menutup semua seluruh permukaan kemudia diamkan selama 1 menit lalu. Preparat yang telah diwarnai kemudian diamati menggunakan mikroskop perbesaran 1000X. Sediaan dibaca sebanyak 100 lapang pandang selam kira-kira 10 menit (Manual prosedul AIM Ziehl Neelsen 2016).

Penilaian pelaporan yang digunakan adalah sebagai berikut:

1. Negatif : Tidak ditemukan BTA/100 lapang pandang.

2. Scienty : 1-9 BTA/100 lapang pandang.

3. Positif $1: 10-99 \mathrm{BTA} / 100$ lapang pandang

4. Positif $2: 1-10 \mathrm{BTA} / 1$ lapang pandang

5. Positif $3:>10$ BTA/1 lapang pandang (PBPK, 2009)

\section{Pemeriksaan TB menggunakan M.Tb Ag rapid tes (JD Daniel Biotech)}

Metode yang digunakan pada kit ini adalah Lateral Flow Cromatography. Sampel buffer sebanyak 1,5 $\mathrm{mL}$ dimasukkan ke dalam tabung bead, kemudian sputum sebanyak 500 ul diekstraksikan. Sampel dihomogenkan menggunakan pipet droper selama 10-20 detik, setelah itu dihomogenkan menggunakan vortex mixer selama 30-60 detik. Sampel diinkubasi pada $37^{\circ} \mathrm{C}$ selama 60 disentrifugasi pada $3000 \mathrm{rpm}$ selama 5 menit (sampai terlihat larutan partikel yang besar berada didasar tabung). $100 \mathrm{uL}$ supernatan yang sudah disentrifugasi dimasukkan kedalam tabung plastik dan ditambahkan $100 \mathrm{uL}$ sampel buffer kemudian dihomogenkan. Campuran dibaca selama 30 menit. Interpretasi hasil positif akan terlihat dua garis di area kontrol dan tes. Hasil menunjukkan negatif apabila hanya terlihat satu garis pada area kontrol saja (Manual Prosedur JD Daniel 2016). 


\section{HASIL}

Pengamatan gambaran pewarnaan BTA dan deteksi menggunakan MTb antigen rapid pada penderida TB paru didapatkan hasil seperti yang ditunjukkan pada tabel 1 dan 2 . Tabel 1 menunjukkan bahwa sebanyak 40 sampel yang diujikan didapatkan hasil pewarnaan BTA negatif sebanyak 25 sampel atau $62,5 \%$ dan pewarnaan BTA positif sebanyak 15 sampel atau 37,5\%. Tabel 2 menunjukkan bahwa sebanyak 40 sampel yang diujikan didapatkan hasil M.Tb Ag rapid tes negatif sebanyak 12 sampel atau 30\%, M.Tb Ag rapid tes positif sebanyak 28 sampel atau 70\%. Pada tabel 3 menunjukkan bahwa distribusi sampel berjenis kelamin laki-laki sebanyak 18 sampel atau 45\%, sedangkan pasien perempuan berjumlah 22 sampel atau 55\%. Pada tabel 4 menunjukkan bahwa distribusi sampel berusia < 40 tahun sebanyak 13 sampel atau 32,5\%, sampel berusia 40-60 tahun berjumlah 13 sampel atau 32,5\% dan sampel berusia > 60 tahun berjumlah 14 sampel atau 35\%. Pada tabel 5 menunjukkan bahwa hasil pemeriksaan sampel BTA negatif tetapi M.Tb Ag positif memiliki persentase 35\% dari total sampel. Sedangkan hasil pemeriksaan menunjukkan tidak ada sampel BTA positif tetapi M.Tb Ag negatif.

Tabel 1. Hasil Pewarnaan BTA metode Ziehl Neelsen

\begin{tabular}{ccc}
\hline Pewarnaan BTA & Frekuensi & Persentase (\%) \\
\hline Negatif & 25 & 62,5 \\
Positif & 15 & 37,5 \\
\hline Total & 40 & 100 \\
\hline
\end{tabular}

Tabel 2. Hasil Pemeriksaan M.Tb Ag rapid test

\begin{tabular}{ccc} 
M.Tb Agrapid test & Frekuensi & Persentase (\%) \\
\hline Negatif & 12 & 30 \\
Positif & 28 & 70 \\
\hline Total & 40 & 100 \\
\hline
\end{tabular}

Tabel 3. Distribusi sampel berdasarkan jenis kelamin

\begin{tabular}{ccc} 
Jenis kelamin & Frekuensi & Persentase (\%) \\
\hline Laki laki & 18 & 45 \\
Perempuan & 22 & 55 \\
\hline Total & 40 & 100 \\
\hline
\end{tabular}

Tabel 4. Distribusi sampel berdasarkan kelompok usia

\begin{tabular}{ccc}
\hline Usia & Frekuensi & Persentase $(\%)$ \\
\hline$<40$ tahun & 13 & 32,5 \\
$40-60$ tahun & 13 & 32,5 \\
$>60$ tahun & 14 & 35,0 \\
\hline
\end{tabular}

Tabel 5. Hasil pemeriksaan Pewarnaan BTA dan M.Tb Ag rapid test

\begin{tabular}{cccc}
\hline \multirow{2}{*}{ Kategori } & \multicolumn{2}{c}{ M.Tb Ag } & \multirow{2}{*}{ Total (\%) } \\
& Positif (\%) & Negatif (\%) & \\
\hline BTA Positif & 37,5 & 0.0 & 37,5 \\
BTA Negatif & 35,0 & 27,5 & 62,5 \\
\hline Total & 72,5 & 27,5 & 100 \\
\hline
\end{tabular}




\section{PEMBAHASAN}

Pada penelitian ini dilakukan pewarnaan BTA dengan teknik pemanasan menggunakan reagen Ziehl Nelseen (ZN). Prinsip dari pemeriksaan pewarnaan ini adalah Bakteri tahan asam (BTA) mempunyai dinding sel dengan pori-pori yang sangat rapat dan sulit ditembus zat warna. Pemberian zat warna pertama (carbol fuchsin) dilakukan pemanasan dengan tujuan memperbesar pori- pori sehingga zat warna karbol fuchsin dapat masuk ke dalam sel bakteri melalui dindingnya. Pori-pori dinding sel akan merapat kembali setelah dingin, sehingga pada saat pencucian dengan asam alkohol, zat warna yang ada di dalam tubuh bakteri tidak terlepas, sedangkan bakteri tidak tahan asam akan melepas zat warna pertama. Setelah penambahan zat warna kedua (methylene blue) bakteri tidak tahan asam akan mengambil zat warna tersebut (Gupte, 1990). Pada pengamatan di bawah mikroskop bakteri yang tergolong BTA berbentuk batang, seperti tumpukkan kayu berwarna merah dengan latar belakang berwarna biru, sedangkan untuk bakteri bukan BTA akan tampak berwarna biru.

Sekarang ini terdapat kit deteksi Mycobacterium tuberculosis dengan cara cepat yaitu pemeriksaan Mycobacterium tuberculosis antigen rapid (M.Tb Ag rapid). Tes ini merupakan uji serologi untuk mendeteksi antigen M. tuberculosis. Antibodi TB monoklonal dikode oleh gen Region of Different (RD) yang digunakan untuk mendeteksi antigen ESAT-6, CFP-10. Prinsip metode ini adalah reaksi antara antigen dan antibodi untuk mendeteksi antigen $M . T b$. Spesimen sputum yang mengandung antigen $M . T b$ diekstrasikan dengan sampel buffer dan didiamkan. Supernatan diteteskan ke dalam lubang sampel, cairan akan bermigrasi melalui daerah penyerapan membran menuju lapisan dye-antibody conjugate kemudaian ikatan komplek antibodi-antigen bergerak ke area tes dan berikatan dengan antibodi yang terdapat di area tes. Hasil positif akan menunjukkan garis warna merah muda pada area tes (T), selanjutnya ikatan komplek bergerak menuju lapisan antibodi pada area kontrol (C). Jika muncul garis berwarna merah muda pada garis kontrol menunjukkan kit bekerja dengan baik (Manual Prosedur JD Daniel 2016).

Tahapan penambahan sampel bufer berfungsi sebagai pencuci untuk menstabilkan protein, sebagai agen pelarut membran protein dan melisiskan sel mamalia. Tujuan ekstraksi dengan sampel bufer adalah untuk memisahkan/mengekstrasi protein-protein yang spesifik dari spesimen (specific secreted protein from sputum). Proses homogenisasi bertujuan untuk memecah sampel sehingga menjadi lebih halus pada sampel-sampel yang bersifat lekat dan kental. Inkubasi bertujuan untuk mengendapkan partikel-partikel berukuran besar ke dasar tabung. Fungsi sentrifugasi yaitu untuk memisahkan partikel- partikel hasil ekstraksi yang berukuran lebih besar menuju kebagian dasar tabung. Supernatan yang mengandung protein TB antigen spesifik akan terdeteksi sehingga memunculkan hasil positif (Manual Prosedur JD Daniel 2016).

Sampel yang diuji pada penelitian ini yaitu 40 sampel dari pasien terduga tuberkulosis baik pasien rawat inap maupun rawat jalan. Berdasarkan jenis kelamin, jumlah pasien perempuan lebih tinggi (22 sampel atau 55\%) dibandingkan dengan laki laki (18 sampel atau 45\%). Hal tersebut sejalan dengan penelitian yang dilakukan Wijayanto et al. (2013) yaitu jumlah sampel perempuan (59\%) lebih tinggi dibandingkan dengan laki laki (40,8\%). Penelitian yang dilakukan oleh Jaya et al. pada tahun 2015 menunjukkan bahwa kasus TB justru lebih banyak dialami oleh pasien laki-laki $(58,2 \%)$ dibandingkan dengan perempuan $(41,8 \%)$ (Jaya et al., 2015). Data yang diperoleh WHO menunjukkan bahwa laki-laki lebih beresiko terinfeksi TB dibanding perempuan. Pada tahun 2015, sebanyak 6 juta laki-laki dewasa terinfeksi TB dan 5 juta diantaranya mengalami kematian, sedangkan perempuan ada 3,5 juta terinfeksi TB diantaranya mengalami kematian 0.5 juta (WHO, 2012).

Perez-Guzman et al. (2003) menyatakan bahwa laki-laki memiliki frekuensi lebih tinggi menderita TB karena laki-laki lebih terkena pajanan yang lebih sering dan pada perempuan TB lebih sering tidak terdiagnosis. Laki-laki lebih cenderung perokokdibandingkan perempuan sehingga perilaku ini membuat perubahan dalam saluran napas yang berakibat pertahanan alami saluran napas melemah. Selanjutnya terdapat perbedaan tingkat kesadaran berobat lebih pada perempuan karena memiliki kesadaran yang baik untuk berobat daripada laki-laki. Hal yang tak kalah pentingnya adalah terdapatnya perbedaan jenis pekerjaan karena memang laki-laki yang lebih banyak bekerja (Amin et al., 2011).

Usia pasien tertinggi pada usia >60 tahun (14 sampel atau 35\%) kemudian diikuti oleh usia $<40$ tahun dan 40-60 tahun yang masing masing 13 sampel (32,5\%). Hasil ini sejalan dengan penelitian Wijayanto et al. (2013) yang menunjukkan bahwa pasien terbanyak pada usia >60 (49\%). Usia termasuk variabel yang penting dalam mempelajari suatu masalah kesehatan karena ada kaitannya dengan daya tahan tubuh 
seseorang. Sedangkan daya tahan tubuh terhadap TB paru ditentukan oleh kemampuan sistem imunitas seluler dan setiap ada faktor yang mempengaruhinya secara negatif akan meningkatkan kerentanan terhadap TB paru (Alisjahbana et al., 2007).

Hasil pemeriksaan TB dengan pewarnaan BTA dan uji rapid antigen M.Tb, menunjukkan bahwa sebanyak 35\% hasil menunjukkan BTA negatif sedangkan uji M.Tb positif. Analisis statistik menunjukkan bahwa ada perbedaan yang signifikan antara hasil pemeriksaan BTA dengan pemeriksaan Rapid antigen $M . T b(\mathrm{p}=0,001)$ pada pasien diagnosis TB. Hasil tersebut sejalan dengan penelitian yang dilakukan oleh Imawan 2013. Hal tersebut dapat terjadi karena dalam pemeriksaan sputum BTA dibawah mikroskop dibutuhkan bakteri $M$. tuberculosis dengan jumlah paling sedikit 5000 bakteri dalam satu milliliter spesimen sputum. Sedangkan pada hasil M.Tb ag rapid tes hasil menunjukkan positif karena pada kit ini mampu mendeteksi adanya antigen dan protein yang disekresi oleh $M$. tuberculosis, sehingga bila spesimen sputum dengan jumlah bakteri dibawah 5000/mL sampel masih dapat dideteksi (Icksan \& Reny, 2008).

\section{KESIMPULAN}

Sputum pasien yang terdiagnosis TB pada penelitian ini berjumlah 40 pasien. Usia pasien tertinggi yaitu usia >60 tahun sebanyak 35\%, usia <40 tahun, dan 40-60 tahun yang masing masing sebanyak 32,5\%. Pasien yang terdiagnosis TB berdasarkan jenis kelamin yaitu 55\% perempuan dan $18 \%$ laki laki. Terdapat perbedaan yang signifikan antara hasil pemeriksaan BTA dengan pemeriksaan Rapid antigen M.Tb $(\mathrm{p}=0,001)$ pada pasien diagnosis TB.

\section{REFERENSI}

Alisjahbana, B., Sahiratmadja, E., Nelwan, E.J., Purwa, A.M., Ahmad, Y., Ottenhoff, T.H., Nelwan, R.H., Parwati, I., van der Meer, J.W., \& van Crevel R. (2007). The effect of type 2 diabetes mellitus on the presentation and treatment response of pulmonary tuberculosis. Clincal Infectious Disease. 45,428435.

Amin, S., Khattak, M.I., Shabbier, G., \& Wazir MN. (2011). Frequency of pulmonary tuberculosis in patient with diabetes mellitus. Gomal Journal of Medical Sciences. 9,163-165.

Gupte, S. (1990). The Short Texbook of Medical Microbiology. Jaypee Brothers: India.

Gustiani, Nenny., Ida parwati., Anna Tjandrawati.,\& Leni Lismayanti, 2014. Validitas pemeriksaan Complex Spesipic Antigen Mycobacterium tuberculosis Region of Different 1-3 metode Rapid. Majalah Kedokteran Bandung. 46(4),241-246.

Icksan, A.G. \& Reny, L. (2008). Radiologi Toraks Tuberculosis Paru. Sagung seto: Jakarta.

Imawan. 2013. Perbedaan hasil pemeriksaan BTA dengan Rapid Test Ag TB pada pasien diagnosis klinis TB paru. Karya Tulis Ilmiah: Fakultas Kedokteran dan Ilmu Kesehatan. Universitas Muhammadiyah Yogyakarta.

Jaya, S.S.K., Burhan, E., Rochsismandoko, \& Cahyarini. (2015). Uji banding pemeriksaan mikroskopis sputum basil tahan asam dengan Xpert MTB/RIF pada pasien diabetes mellitus yang diduga tuberkulosis paru. Journal of Respiratory Indonesia. 35(3),144-157.

Kementerian Kesehatan Republik Indonesia (Kemenkes). (2012). Pedoman Nasional Pengendalian Tuberculosis. Jakarta.

Manual Prosedur Kit AIM Ziehl Neelsen pewarnaan BTA. (2016).

Manual Prosedur Kit JD Daniel Biotech. Mycobacterium tuberculosis. (2016).

Nazarudin, M., Nugraha, J., \& Aryati. (2012). Jurnal Nilai diagnostic Rapid test TbAg dan MPT64 dengan kultur sebagai gold standar. Thesis Universitas Airlangga.

Pendidikan Berkesinambungan Patologi Klinik (PBPK). (2009). Lokarya pembuatan, pewarnaan dan penilaian sediaan Mikrobiologi. Departemen Patologi Klinik. Fakultas Kedokteran Universitas Indonesia: Jakarta.

Perez-Guzman, C., Vargas, M.H., \& Torres- Cruz, A. (2003). Diabetes modifies the male: female ratio in pulmonary tuberculosis. International Journal of Tuberculosis Lung Disease. 7,354-358.

WHO. (2012). Global tuberculosis control.The burden of disease caused by TB. WHO report. 9-12.

Wijayanto, A., Burhan E, Nawas A, \& Rochsismandoko. (2013). Faktor yang Berhubungan dengan Terjadinya Tuberkulosis Paru Pada Pasien Diabetes Melitus Tipe 2 di RSUP Persahabatan. Tesis Departemen Pulmonologi dan Ilmu Kedokteran Respirasi FKUI: Jakarta. 